\title{
圧力制御ループに外乱オブザーバを用いた空気圧駆動系の位置決め制御
}

\author{
則 次 俊 郎*・高 岩 昌 弘*
}

\section{Positioning Control of Pneumatic Servo System with Pressure Control Loop Using Disturbance Observer}

\author{
Toshiro NoRITSUGu* and Masahiro TAKAIWA*
}

This paper describes one method to attain a robust positioning control of pneumatic driving system comprising a pneumatic cylinder and PCM digital control valves.

A pneumatic driving system has become one of interests in the industrial fields, however, the control characteristics are inevitably affected by the friction force and parameter changes of plant due to air compressibility.

The control characteristics of a pneumatic actuator depend on a pressure response. So if a pressure can follow the reference value which compensates the influences of the friction force and the parameter changes of plant, the friction force and the parameter changes of plant do not affect the control characteristics.

A meter out speed control method, widely used in a pneumatic system, is employed. This method has a superior energy efficiency but gives a nonlinear pressure response. From these points of view, we proposed a positioning control system including an active controlled pressure loop.

Two disturbance observers are employed in this control system. One is applied in a pressure control loop to improve the robustness against the influence of the piston speed which acts as a disturbance and to compensate the nonlinearity owing to the meter out method, the other is in kinetic part, from the pressure to the piston speed, to generate the compensating signal to counterbalance the friction force and the parameter changes of plant.

Through some experiments about the robustness against the payload, the positioning accuracy and so on, the validity of this control method has been confirmed.

Key Words : pneumatic servo system, positioning control, pressure control, disturbance observer

\section{1. 緒言}

空気圧アクチュエータは出力重量比が高く, 駆動系の 構成が容易であるため, その高機能化が期待されている. 反面，空気の圧縮性に起因した低剛性により，制御特性 は摩擦力やプラントのパラメータ変動の影響を受けやす いなど，解決すべき問題も残されている.

圧力は一般にプラントの安定化のために用いられ, 著

† 日本機械学会ロボティクスメカトロニクス講演会'94 で発 表 $(1994 \cdot 7)$

* 岡山大学工学部 岡山市津島中 $3-1-1$

* Faculty of Engineering, University of Okayama, Okayama

(Received December 22, 1994)

(Revised April 10, 1995)
者らも圧力フィードバックによるプラントの安定化を 行ってきた1),2).しかし, 新たに圧力制御系を構成し, 摩 擦力やプラントパラメータ変動の影響を補償できる圧力 が生成されれば,これらの変動に対してロバストな制御 系を構成できる。この点に着目して, 宮田らは, 空気圧 シリンダの圧力応答に外乱として作用するピストン速度 の影響をフィードフォワード的に相殺する手法を提案し ている3).しかし，摩擦力などの補償は行われていない. さらに, ピストン位置に依存する圧力応答特性の変化を 補償する可変ゲイン PD コントローラを用いた圧力制御 系を構成 4 し, 摩擦力の補償を行っているが, 荷重印加な どに起因するプラントパラメータ変動の影響までは考慮 されていない.

本研究では, 圧力制御系に外乱オブザーバを応用し, 
これに基づいて空気式スライドテーブルの位置決め制御 を行う。駆動方式は，空気圧系において一般に使用され るメータアウト方式とする．この方式は 3 ポート弁を用 いた圧力制御方式に比べて，エネルギー効率に優れる反 面，後述するように，制御信号から両シリンダ室の圧力 差の伝達部に非線形性が生じ, 制御性能の悪化につなが る。外乱オブザーバによれば外乱および制御対象のパラ メー夕変動を推定かつ補償できるため, 摩擦力やピスト ン速度の影響と，メータアウト方式に起因する圧力応答 の非線形性や荷重変化時のパラメー夕変動の影響を低減 することができる.

まず，外乱オブザーバを用いた圧力制御系の構成を示 した後，その制御性能を通常の PI 制御によるものと比 較する、続いて，この圧力制御系を主体とした位置制御 系を構成する．種々の実験を通して提案した制御系の有 効性が確認され, 荷重変動に対するロバスト性と, 空気 圧系として十分な位置決め精度が得られている。

\section{2. 制御系の構成}

\section{1 空気圧駆動回路のモデル}

Fig. 1 に空気圧駆動回路のモデルを示す. $p_{l}, p_{r}, p_{s}, p_{A}$ はそれぞれ左側シリンダ室圧力，右側シリンダ室圧力， 供給圧力および大気圧であり $, x, f_{c}, m, b, A, V, T, S$, $G_{p}$ はそれぞれピストン変位, クーロン摩擦力, ピストン 質量, 粘性摩擦係数, ピストン受圧面積, シリンダ室容 積, 空気の絶対温度, 弁開口面積および空気質量流量で ある。

両シリンダ室が供給圧力 $p_{s}$ で加圧され,テーブルがシ リンダ中央で静止している状態を平衡状態とする．右側 シリンダ室の状態方程式は次式で表わされる5). $R, \varkappa$ は それぞれガス定数および比熱比である

$$
\frac{d p_{r}}{d t}=-\frac{\varkappa R T}{V} G p+\frac{\varkappa p_{r} A}{V} \frac{d x}{d t}
$$

ここで，制御弁を通過する空気は音速流と仮定すれば， 質量流量 $G_{p}$ は次式で表わされる。

$$
G_{p}=S p_{r} \sqrt{\frac{2}{R T} \frac{\chi}{\chi-1}\left(\frac{2}{x+1}\right)^{2 /(\kappa-1)}}
$$

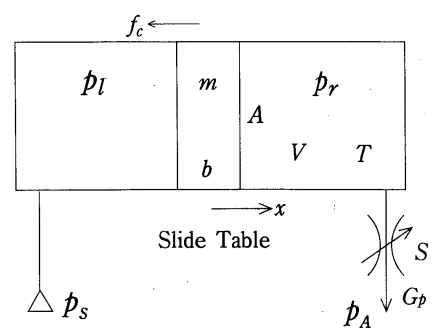

Fig. 1 Symplified Model of Plant
弁開口面積 $S$ は制御信号 $u$ に比例する $\left(S=k_{s} u\right)$ と仮 定する.またシリンダ室差圧 $p_{d}=p_{l}-p_{r}$ を用いて, $p_{l}=$ psを考慮すれば，（1 ) 式は，

$$
\begin{aligned}
\frac{d p_{d}}{d t}= & \frac{\chi k_{s}}{V} \sqrt{\frac{2 R T \chi}{\chi-1}\left(\frac{2}{\chi+1}\right)^{2 /(\kappa-1)}}\left(p_{s}-p_{d}\right) u \\
& -\frac{\chi\left(p_{s}-p_{d}\right) A}{V} \frac{d x}{d t}
\end{aligned}
$$

となる. $p_{d}$ の過渡特性は $u$ およびテーブル速度に依存 し, $p_{d}$ の定常值は $d x / d t=0, u \neq 0$ のとき $u$ によらず常 に供給圧力 $p_{s}$ に収束する。このように, $u$ から $p_{d} へ$ の 伝達部には非線形性が存在する.

テーブルの運動方程式は次式で表わされる.

$$
p_{d}=\frac{m}{A} \frac{d^{2} x}{d t^{2}}+\frac{b}{A} \frac{d x}{d t}+\frac{f_{c}}{A} \operatorname{sgn}\left(\frac{d x}{d t}\right)
$$

\section{2 圧力制御系の構成}

Fig. 2 は外乱オブザーバ6)を用いた圧力制御系を示 す. ピストン速度の影響を外乱とみなし, 外乱オブザー バによりピストン速度の影響と圧力応答の非線形性を補 償する. 変数は大文字でラプラス変換を示し, 伝達関数 の $(s)$ は省略する. $P_{\text {ref }}$ は圧力目標值であり, $P_{1 n}, Q_{1}$ は それぞれ $U$ から $P_{d}$ への伝達部に対する線形ノミナル モデルおよびフィルタである， $P_{d}$ が $P_{r e f}$ に対して自己 平衡性を有すると同時に，できるだけ応答遅れが小さく なるように，ノミナルモデルは 1 次遅れとする.

簡単のため (3) 式を $(5)$ 式により線形近似すると，圧 力制御系の入出力特性は (6) 式で与えられる.

$$
\begin{aligned}
P_{d}= & \alpha U-\beta s X \\
P_{d}= & \frac{\left(1-Q_{1}\right)^{-1}}{\alpha^{-1}+P_{1 n}^{-1} Q_{1}\left(1-Q_{1}\right)^{-1}} P_{r e f} \\
& -\frac{\alpha^{-1} \beta}{\alpha^{-1}+P_{1 n}^{-1} Q_{1}\left(1-Q_{1}\right)^{-1}} s X
\end{aligned}
$$

$Q_{1}=1$ とみなせる周波数領域では, 閉ループ伝達関数 はノミナルモデル $P_{1 n}$ に固定されると同時に, $P_{d}$ の応答 にピストン速度の影響は現れない. しかし, 安定性を維 持するためには高周波領域で $Q_{1}=0$ となることが望まし い.このため， $Q_{1}$ は低域濾過特性を有するように設定さ れ, $Q_{1}$ の時定数 $T_{p q}$ は低感度化と安定性のトレードオ フにより決定される。

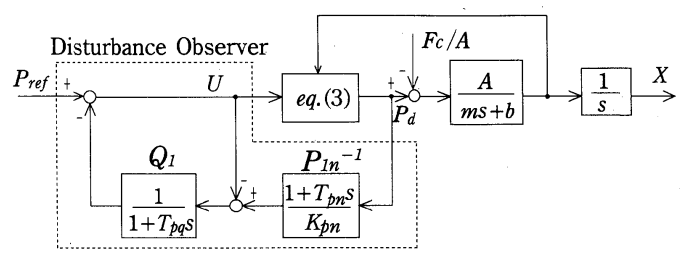

Fig. 2 Pressure Control System Using Disturbance Observer 


\subsection{PI 制御系との特性比較}

Fig. 3 に PI 制御系による圧力制御系を示す.（5 ) 式 を用いると入出力特性は

$$
\begin{aligned}
P_{d}= & \frac{C_{\mathrm{PI}}}{\alpha^{-1}+K_{p n}^{-1} C_{\mathrm{PI}}} P_{r e f} \\
& -\frac{\alpha^{-1} \beta}{\alpha^{-1}+K_{p n}^{-1} C_{\mathrm{PI}}} s X
\end{aligned}
$$

となる。 $C_{\mathrm{PI}}$ は PI コントローラを示す。ピストン速度を 外乱とみなした場合，その抑圧特性が両制御系で等しく なる条件は, (6)式，（7) 式の右辺第 2 項を比較して,

$$
K_{p n}^{-1} C_{\mathrm{PI}}=P_{1 n}^{-1} Q_{1}\left(1-Q_{1}\right)^{-1}
$$

となる。（8)式は口バスト安定性が等しくなる条件でも ある，それぞれの変数を代入して，つぎの関係が成り立 ว.

$$
\left.\begin{array}{l}
g_{p}=T_{p n} T_{p q}^{-1} \\
g_{i}=T_{p q}^{-1}
\end{array}\right\}
$$

このとき（6)式，(7)式の右辺第 1 項に示される圧力 制御系の閉ループ伝達関数のゲインは, 外乱オブザーバ を用いた場合, $\mathrm{PI}$ 制御系の $\left|P_{1 n} Q_{1}^{-1} K_{p n}^{-1}\right|$ 倍となる.よっ て, 同じ感度特性下での両制御系のバンド幅はフィル夕 時定数 $T_{p q}$ とノミナルモデルの時定数 $T_{p n}$ の大小関係 により比較することができる.

\section{4 位置制御系の構成}

Fig. 4 に提案する位置制御系を示す. 摩擦力の影響を 低減するとともに荷重変化によるパラメー夕変動を補償 するため, 圧力 $P_{d}$ からテーブル速度 $s X$ までのプラン ト $P_{2}$ に対して新たに外乱オブザーバを付加する. 次式 に示すように推定外乱 dis にはプラントのパラメータ変 動および摩擦力が含まれる。

$$
\begin{aligned}
d i s= & \frac{m_{n}-m}{A} \frac{d^{2} x}{d t^{2}}+\frac{b_{n}-b}{A} \frac{d x}{d t} \\
& -\frac{f_{c}}{A} \operatorname{sgn}\left(\frac{d x}{d t}\right)
\end{aligned}
$$

dis は内部安定性を保証するためのフィルタ $Q_{2}$ を介し て圧力制御系の目標值 $P_{\text {ref }}$ に加えられる. dis から $P_{d}$ までの定常ゲインを 1 にするため, $Q_{2}$ には圧力制御系の 閉ループ定常ゲイン $K_{p n}$ の逆数を乗じている.

圧力制御系が理想的に動作し，その閉ループ伝達関数 がノミナルモデル $P_{1 n}$ に一致していると仮定すれば。つ ぎの関係が得られる。

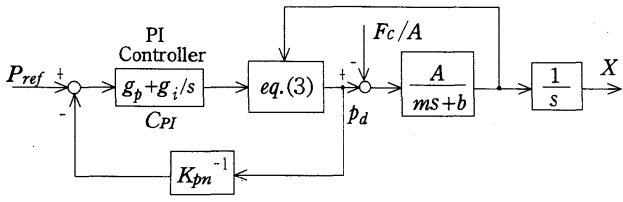

Fig. 3 Pressure Control System Using PI controller

$$
\begin{aligned}
s X= & \frac{1}{P_{1 n}^{-1} P_{2}^{-1}\left(1-Q_{2} P_{1 n}\right)+Q_{2} P_{2 n}^{-1}} P_{r e f} \\
& -\frac{P_{1 n}^{-1}\left(1-Q_{2} P_{1 n}\right)}{P_{1 n}^{-1} P_{2}^{-1}\left(1-Q_{2} P_{1 n}\right)+Q_{2} P_{2 n}^{-1}} \frac{F_{c}}{A}
\end{aligned}
$$

$Q_{2} P_{1 n}=1$ とみなせる周波数域において, 摩擦力の影響は $s X$ に現れず，P $P_{\text {ref }}$ から $s X$ までの伝達関数は次式に示 すようにそれぞれのノミナルモデルの積で表わされる.

$$
\frac{s X}{P_{r e f}}=P_{1 n} P_{2 n}=\frac{K_{p n}}{1+T_{p n s}} \frac{A}{m_{n} s+b_{n}}
$$

$P_{\text {ref }}$ から $X$ までは 3 次系となるが, 圧力制御系の時 定数 $T_{p n}$ は小さく設定できるものと考え，実現すべき閉 ループ伝達関数を次式の 2 次系で与える.

$$
\frac{X}{X_{r}}=\frac{\omega_{n}^{2}}{s^{2}+2 \zeta \omega_{n} s+\omega_{n}^{2}}
$$

変形して,

$$
s X=\frac{\omega_{n}^{2}}{s+2 \zeta \omega_{n}}\left(X_{r}-X\right)
$$

(12) 式において， $T_{p n}=0$ とおけば，(13) 式を満足するた めの $P_{r e f}$ は位置偏差 $X_{r}-X$ から次式に示すコント ローラ $C$ を介して算出される.

$$
C=\frac{\omega_{n}^{2} K_{p n}^{-1} A^{-1}\left(m_{n} s+b_{n}\right)}{s+2 \zeta \omega_{n}}
$$

なお, Fig. 4 において, 圧力 $P_{d}$ は $Q_{1} P_{1 n}^{-1}$ および $Q_{2}$ を 通してフィードバックされ，その伝達特性は次式のよう にまとめられる。

$$
\frac{Q_{1}}{P_{1 n}}-Q_{2}=\frac{s\left(T_{m q}+T_{p n}-T_{p q}+T_{m q} T_{p n} s\right)}{K_{p n}\left(1+T_{p q} S\right)\left(1+T_{m q} S\right)}
$$

(16) 式に示す伝達関数が非最小位相となると位相が大き く減少し，まとめたフィードバックループにより構成さ れる系の安定性を低下させる恐れがある，そのため，各 パラメータは次式を満足する必要がある。

$$
T_{m q}+T_{p n}-T_{p q}>0
$$

\section{3. 空気圧駆動系}

Fig. 5 に空気圧駆動系を示す．空気圧ロッドレスシリ ンダ (内径 $25 \mathrm{~mm}$ ，ストローク $800 \mathrm{~mm}$ ) を内蔵したスラ イドテーブルを水平に設置する，供給圧力はゲージ圧で $p_{s}=440 \mathrm{kPa}$ である．テーブルの変位はプーリを介して

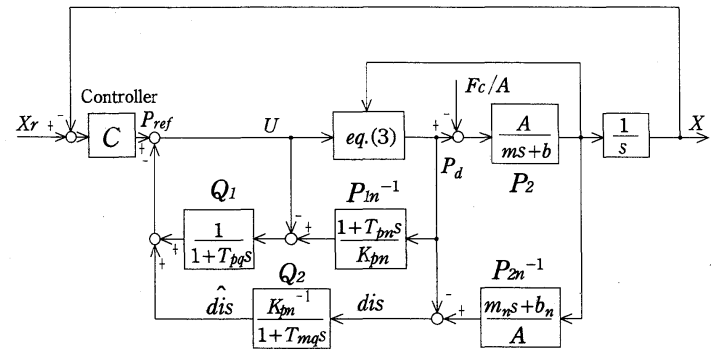

Fig. 4 Positioning Control System 


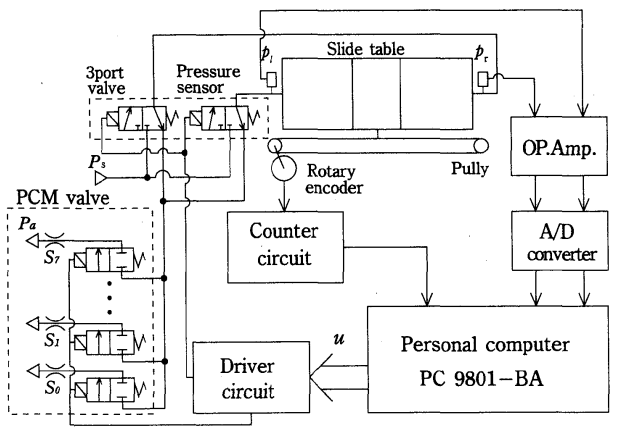

Fig. 5 Pneumatic Driving System

ロータリーエンコーダ(分解能 $7.8 \mu \mathrm{m}$ ) で検出し, 圧力 $p_{d}$ は両シリンダ室に取り付けられた圧力センサ(分解能 $0.52 \mathrm{kPa}$ )の検出信号から算出する.これらの検出信号 はそれぞれカウンタおよび $\mathrm{A} / \mathrm{D}$ 変換器を通して制御用 コンピュータに入力される。コンピュータで計算された 制御信号 $u$ は弁ドライバ回路を介して 3 ポート電磁弁 と 8 ビットの PCM 弁 ${ }^{7)}$ 駆動する. 3 ポート電磁弁は テーブルの移動方向を切り換え, PCM 弁はメータアウ ト方式によりテーブル速度を調節する. 制御信号 $u$ は $-255 \leq u \leq 255$ の整数であり，その符号が 3 ポート電磁 弁, 絶対值が PCM 弁の駆動信号に対応する. $u=0$ のと き, ピストン停止時の剛性を高めるため, 両 3 ポート弁 を $0 \mathrm{~N}$ にして両シリンダ室を $p_{s}$ で加圧する. 制御プロ グラムは C 言語で記述し,サンプリングタイムは $0.2 \mathrm{~ms}$ である。

\section{4. 実験結果および考察}

\section{1 外乱オブザーバの効果}

\subsection{1 圧力制御系における効果}

Fig. 6 はテーブルをストローク中央に固定し，制御信 号 $u=50,100,200$ を印加したときの圧力 $p_{d}$ の応答を示 す.（3) 式に示したように, 過渡応答は $u$ に大きく依存 し, $p_{d}$ は $u$ によらず供給圧力 $p_{s}=440 \mathrm{kPa}$ に収束する. 圧力制御系におけるノミナルモデルを設定する. Fig. 4 に示す制御系において，両外乱オブザーバが理想的に 動作した場合， $Q_{2} P_{1 n}=1$ とみなせる周波数域では， $T_{p n}$ を考慮すると，閉ループ伝達関数は

$$
\frac{X}{X_{r}}=\frac{\omega_{n}^{2}}{s\left(s+2 \zeta \omega_{n}\right)\left(1+T_{p n} s\right)+\omega_{n}^{2}}
$$

となる. 駆動系の速応性の限界を考慮して, $\omega_{n}=8 \mathrm{rad} / \mathrm{s}$, $\zeta=1.0$ とする.さらに，(18)式に基づいたステップ応答 のシミュレーションにより，行き過ぎが生じないように $T_{p n}=0.01 \mathrm{~s}$ に設定する.また, 定常ゲイン $K_{p n}$ は, 圧力 制御系が安定で，かつ，できるだけバンド幅が高くなる

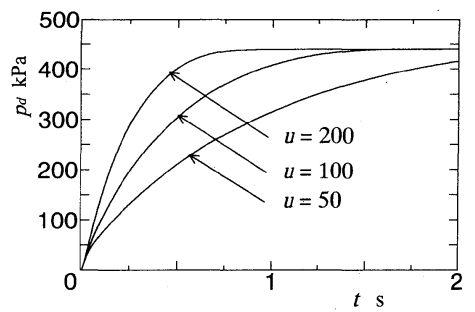

Fig. 6 Pressure Response

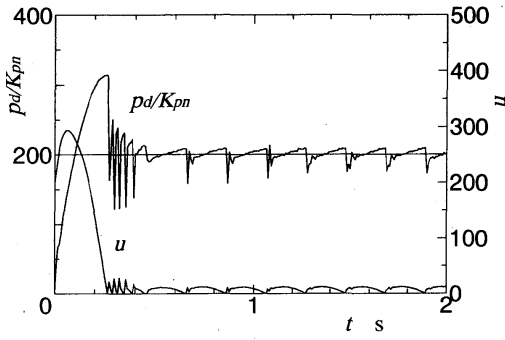

(a) $T_{p q}=0.05 \mathrm{~s}$

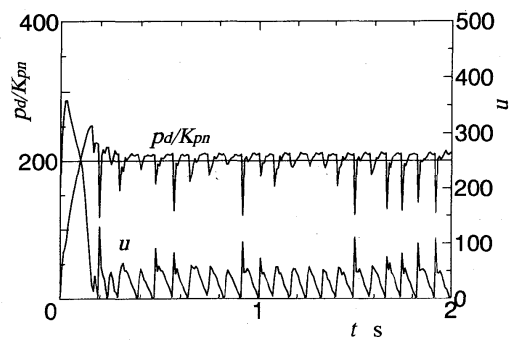

(b) $\quad T_{p q}=0.01 \mathrm{~s}$

Fig. 7 Step Response in Pressure Control System

ように求めている. $K_{p n}=1 \mathrm{kPa}$ とする.

Fig. 7 はテーブルをストローク中央に固定し, Fig. 2 の制御系において, $p_{r e f}=200$ のステップ応答を行った結 果である.（a ）は $T_{p q}=0.05 \mathrm{~s} ，(\mathrm{~b})$ は $0.01 \mathrm{~s}$ の場合であ る。定常状態において周期的な振動が生じる。（3)式よ りわかるように, $u>0$ である限り $p_{d}$ は供給圧力 $p_{s}$ に向 かって増加するため, $p_{d}$ は目標値 $p_{r e f} K_{p n}\left(<p_{s}\right)$ をかなら ず超える.Fig. 2 に扔いて $U$ から $Q_{1}$ を通るフィード バックループは等価的に積分要素を有するため, $p_{d}$ が $p_{r e f} K_{p n}$ を超えると被積分量が負となり $u$ は減少する. 本制御系では， $u=0$ のとき両方の 3 ポート弁を ON と し, 両シリンダ室を $p_{s}$ で加圧するため, $u=0$ のとき $p_{d}$ は急激に低下する，以後同様のサイクルを繰り返す。

フィルタ $Q_{1}$ が 1 に近づくほど，圧力制御系の閉ルー プ伝達関数はノミナルモデル $P_{1 n}$ に近づく，そのため, (b)の応答は ( a ) に比べてオーバーシュートが小さく, モデルの応答に近づく．しかし，先述の等価的な積分ゲ 
インがフィルタ時定数 $T_{p q}$ の逆数に相当するため, $T_{p q}$ が小さくなると積分効果が増大し， $u$ はより振動的とな る. $u$ が振動的になると, 定常状態におけるシリンダ室 からの空気の排気量が増大し, 圧力変動も大きくなる.

\subsection{2 外乱補償効果}

Fig. 4 において $u$ に一定值を印加してテーブルを駆 動し, $t=0.8 \mathrm{~s}$ にをステップ状に増加させた場合の, テーブル速度 $d x / d t$ と推定外乱 $\hat{d} i s$ の測定結果を Fig. 8 に示す. $K_{p n}=1 \mathrm{kPa}$ とし, $Q_{2}$ の時定数 $T_{m q}$ は小さく設 定するほど外乱推定時の遅れが改善されるが次節で述べ る $T_{p q}$ の值を考慮し, (17) 式より $T_{m q}=0.06 \mathrm{~s}$ とする. ミナルモデル $P_{2^{n}}$ のパラメータは無負荷時の同定より, $A / b_{n}=8.5 \times 10^{-3} \mathrm{~m} /(\mathrm{skPa}), m_{n} / b_{n}=0.08 \mathrm{~s}$ とする.

（a）は無負荷時，（b)はテーブル上に $10 \mathrm{~kg}$ の負荷を 載せた場合である. ( a )では, $P_{2}=P_{2 n}$ がほぼ成立してい るため, $Q_{2}$ による推定の遅れを無視すれば, $\widehat{d} i$ にには圧 力換算のクーロン摩擦力のみが現れている. その推定值 はあらかじめ測定した值 $\left(f_{c} / A \approx 20 \mathrm{kPa}\right)$ とほぼ一致し ている.（b)の場合は, 質量変動 $m_{n}-m$ に起因する項 ((10)式右辺第 1 項)が, 摩擦力に加えて現れている. $t \approx$ $1 \mathrm{~s}$ において, テーブルは一定加速度 $1.6 \mathrm{~m} / \mathrm{s}^{2}$ を有する. (10)式より， $m_{n}-m$ に関する項の計算値は約 $-32 \mathrm{kPa}$ となり, 実験值とほぼ一致している.これらょり, 外乱 オブザーバは摩擦力およびプラントパラメータ変動の影 響を同時に推定可能であることがわかる.

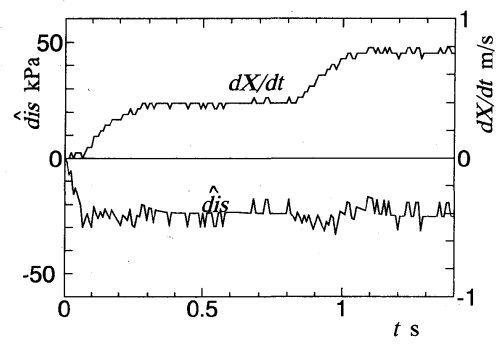

(a) Without Payload

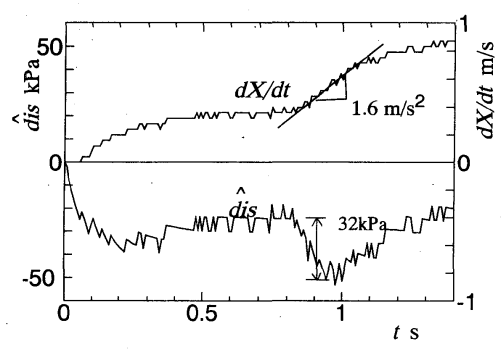

(b) With Payload

Fig. 8 Effect of Disturbance Observer in Estimating Disturbance

\section{2 位置決め制御}

\subsection{1 圧力制御系のフィル夕の影響}

位置決め性能に及ぼす圧力制御系のフィルタの影響を 調べる.Fig.9 は, Fig. 4 に示す位置制御系において, 目 標位置 $x_{r}=0.5 \mathrm{~m}$ のステップ応答を行った結果である. (a)は $T_{p q}=0.05 \mathrm{~s}$ ，(b)は $T_{p q}=0.01 \mathrm{~s}$ の場合である. Fig. 7 に示したように ( a ) は ( b ) に比べて圧力応答に大 きなオーバーシュートが発生するため, $t \approx 0.5 \mathrm{~s}$ 付近で の応答に大きな振動が生じ，その影響によりテーブル位 置 $x$ は若干振動的な応答となる. しかし, 定常状態では $u$ は 0 に収束するため, $p_{d}$ はほぼ一定值を維持し, テー ブルも静止状態を保つ.

一方，（b ）の場合，圧力制御系の特性がノミナルモデ ルに近づくため, 過渡状態で圧力応答に大きな振動は見 られず, テーブル位置 $x$ も滑らかな過渡応答を示す.し かし, 定常状態で $u$ が振動的となり, その結果, $p_{d}$ が増 加し, やがて静止摩擦力を超えてテーブルを再び移動さ せる. 圧力制御系のフィル夕の時定数の設定には注意を 要する. 以下では $T_{p q}=0.05 \mathrm{~s}$ とする.

\subsubsection{PI 制御系との特性比較}

Fig. 10 はテーブルをほぼストローク中央で固定し， $p_{\text {ref }}$ に振幅 200 の正弦波信号を印加して周波数応答を測 定した結果である。・は Fig. 2 を，○は Fig. 3 の制御系 を用いた場合である.PI 制御器の各ゲインは (9)式より $g_{p}=0.2, g_{i}=20 \mathrm{~s}^{-1}$ とした. Fig. 2 の制御系は $T_{p q}>T_{p n}$ と設定されているため, 両制御系において外乱抑圧特性 を等しく設定すると，（6)式および( 7 )式より外乱オブ

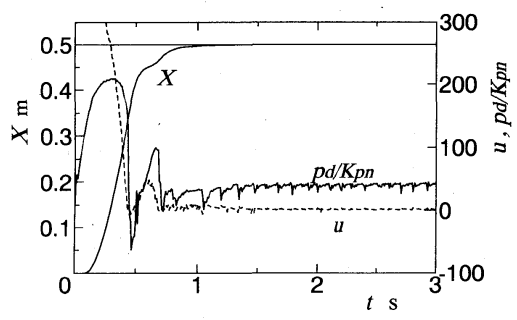

(a) $T_{p q}=0.05 \mathrm{~s}$

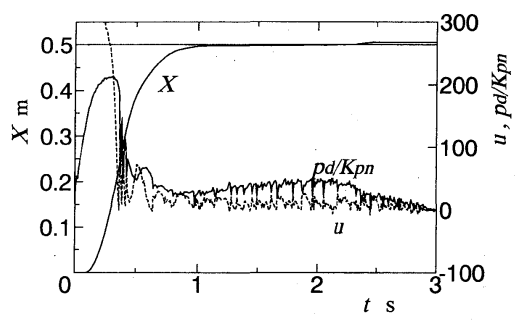

(b) $T_{p q}=0.01 \mathrm{~s}$

Fig. 9 Influence of $T_{p q}$ on Positioning Property 


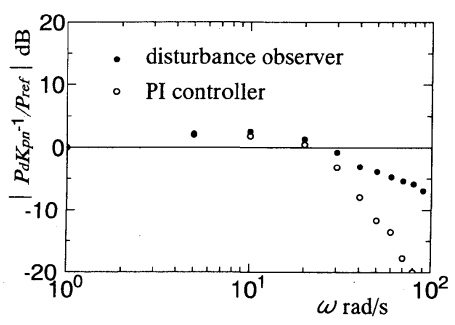

Fig. 10 Frequency Response in Pressure Control System

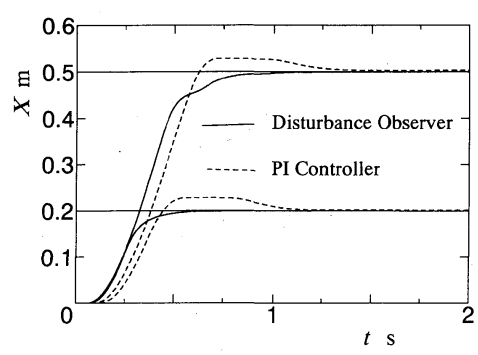

Fig. 11 Comparison with PI Controller (without Payload)

ザーバを用いた場合のほうが圧力制御系のバンド幅が広 くなることがわかる. 推定外乱 $\widehat{d} i$ に による補償効果を向 上させるには圧力制御系のバンド幅はできるだけ広いこ とが望ましい. よって, 圧力制御系に外乱オブザーバを 用いた場合のほうが，荷重変化などに対して優れたロバ スト性を有することが予想される.

ステップ応答を行った結果を Fig. 11 に示す. 実線は Fig. 4 に示す制御系を用いた場合, 点線は Fig. 4 の圧力 制御部に Fig. 3 に示す制御系を用いた場合である. 外乱 オブザーバを用いた場合はオーバーシュートのない良好 な応答が得られている.PI 制御を用いた場合は, 圧力制 御系のバンド幅が外乱オブザーバを用いた場合に比べて 小さいため, 制御量の速応性が劣る. また, 圧力制御系 のバンド幅が狭いと，圧力制御系の遅れが無視できなく なり, 制御量にオーバーシュートが生じやすくなる。こ れは，(18)式において，時定数 $T_{p n}$ が大きい場合に相当 する:

Fig. 12 はテーブル上に $10 \mathrm{~kg}$ の負荷を載せ, $x_{r}=0.5$ m のステップ応答を行った結果である. (a ) は Fig. 4 の 制御系を用いた場合，（b ）は圧力制御部に Fig. 3 の制御 系を用いた場合である.点線は $p_{r e f}$ と $\hat{d} i s$ 差であり, 圧力制御系の目標信号に相当する. $0<t<0.5 \mathrm{~s}$ に扔い て，(a)，（b ) ともに圧力制御系の目標信号の変化に差 は見られないが，（a ）では（b )よりも圧力制御系のバン ド幅が広いため, $p_{d}$ は目標信号の減少に伴い, より早く

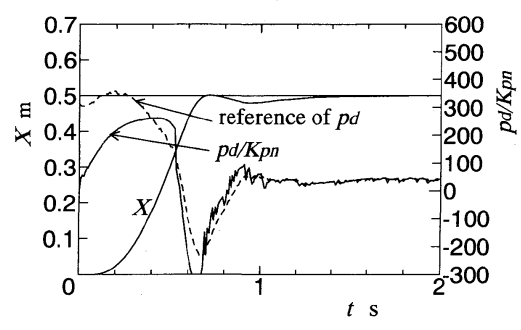

(a) Disturbance Observer

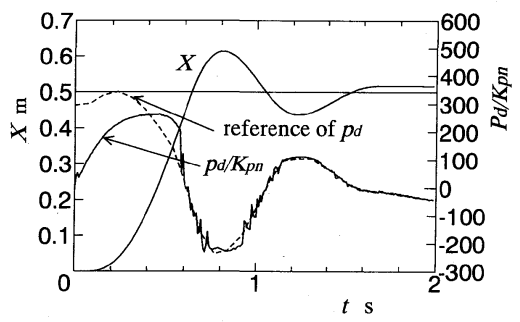

(b) PI Controller

Fig. 12 Comparison with PI Controller (with Payload)

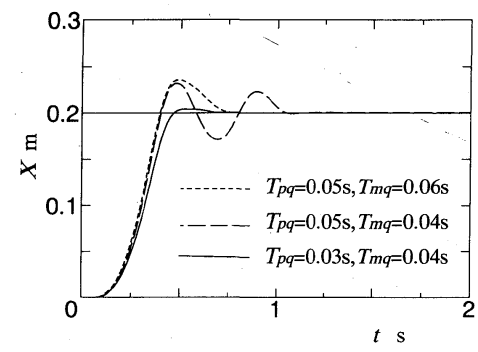

Fig. 13 Improvement of robustness for Payload

低下している．その結果，荷重増加時にも制御量にオー バーシュートが生じにくくなる，また，ピストン位置も 目標值に速やかに収束している.

4.2.3 ロバスト性の改善

Fig. 12（a）に示した実験において $x_{r}=0.2 \mathrm{~m}$ とした 場合, Fig. 13 の点線で示すように制御量に若干オーバー シュートが発生した。荷重変化時のロバスト性を向上さ せるためには, 圧力応答の速応性の向上と, フィルタ $Q_{2}$ による伝達遅れの低減が考えられる。本制御系では，圧 力応答の速応性改善はこれ以上期待できないと考え, フィル夕 $Q_{2}$ の伝達遅れを低減するために, その時定数 $T_{m q}$ を $0.04 \mathrm{~s}$ に減少させた。その結果を破線で示す。こ の場合, (17) 式が満足されず, (16)式を通るフィードバッ クループにより構成される系の安定性が低下し, 応答も 振動的となる.そこで，(17)式を満足するように $T_{p q}$ を $0.03 \mathrm{~s}$ に減少した結果を実線で示す. 若干のオーバー 


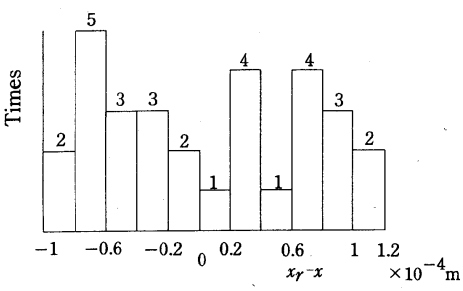

(a) $x_{r}=0.5 \mathrm{~m}$

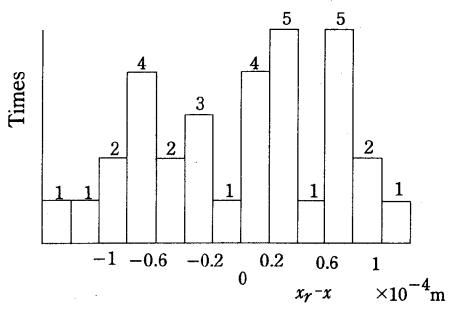

(b) $x_{r}=0.2 \mathrm{~m}$

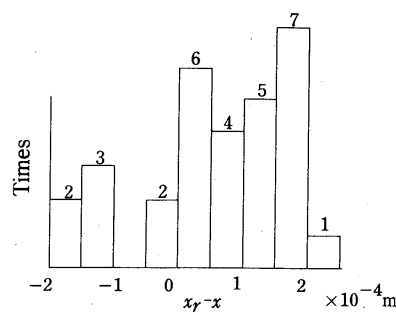

(c) $x_{r}=0.5 \mathrm{~m}$

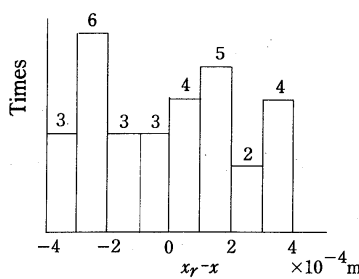

(d) $x_{r}=0.2 \mathrm{~m}$

Fig. 14 Positioning Accuracy

シュートが生じるものの, 優れたロバスト性が確認でき る.ただし， $T_{p q}$ をさらに小さくすれば，Fig. 9(b)で示 したように定常特性を悪化させる可能性があるので注意 する必要がある。

\section{2 .4 位置決め精度}

Fig. 14 はステップ応答を 30 回試行し, 制御動作開始 2 秒後の位置偏差 $x_{r}-x$ を示す。（a )，(b) は荷重がな い状態で, それぞれ目標值 $x_{r}=0.5 \mathrm{~m}$ および $x_{r}=0.2 \mathrm{~m}$ に対する結果であり, (c ), (d) はテーブル上に $10 \mathrm{~kg}$ の 荷重を載せた場合である，荷重がない場合は目標位置の ほぼ $\pm 0.1 \mathrm{~mm}$ 以内に, 荷重を載せた場合は若干精度が 低下するが, 目標位置のほぼ $\pm 0.4 \mathrm{~mm}$ 以内に収まり, 空気压系として十分満足できる位置決め精度が得られ た.

\section{5. 結言}

空気圧アクチュエータの動作は圧力応答特性に強く依 存するため, 圧力制御系を主体とした位置制御系を構成 し, 空気式スライドテーブルの位置決め制御に応用した。 おもな内容と得られた結果を以下に示す.

1）駆動方式はメータアウト方式とした. 本方式はエ ネルギー効率に優れる反面, 圧力応答特性に非線形性を もたらす。これに対して, 外乱オブザーバを用いた圧力 制御系を構成することにより，外乱として作用するピス トン速度の影響とメータアウト駆動方式に起因する非線 形性の補償を行うことができる，また，摩擦力や荷重変 化に伴うプラントパラメータ変動の影響を補償するため
に, 圧力からテーブル速度までの伝達部にも外乱オブ ザーバを付加した。

2）構築した制御系の制御性能を圧力制御系に通常の PI 制御を応用した場合と比較した. 外乱として作用する ピストン速度が圧力に及ぼす影響を等しく設定すると， 両圧力制御系のバンド幅は，外乱オブザーバのフィルタ 時定数 $T_{p q}$ とノミナルモデルの時定数 $T_{p n}$ の大小関係 により比較できる，本研究では，定常特性と閉ループ系 の応答を考慮して $T_{p q}$ と $T_{p n}$ を設定した。その結果，外 乱オブザーバを用いた制御系のほうがバンド幅が広く， PI 制御を用いた場合に比べて, 荷重変化に対して優れた ロバスト性が得られた。

3）位置決め誤差は，荷重を載せた場合はほぼ \pm 0.4 $\mathrm{mm}$ 以内に，荷重がない場合はほぼ $0.1 \mathrm{~mm}$ 以内に収 まり，空気圧駆動系として十分満足できる位置決め精度 が得られた。

以上，圧力制御系の構成による圧力応答の改善が，空 気圧駆動系の制御性能向上に有効であることが確認され た。

\section{参 考 文 献}

1）則次, 高岩：外乱オブザーバを用いた空気圧サーボ系のイ ンピーダンス制御，計測自動制御学会論文集，30-6，677/ 684 (1994)

2）則次,高岩：外乱オブザーバを用いた空気圧位置決め制御 系の設計, 計測自動制御学会論文集, 31-1, 82/88（1995）

3）宮田,花房：圧力制御を主体とした空気圧シリンダの速度 制御, 計測自動制御学会論文集, 26-7, 773/779（1990）

4）宮田, 石田, 花房：可変ゲイン圧力制御系を含む二重構造 
フィードバック制御による空気圧シリンダの位置決め, 計 測自動制御学会論文集, 26-7, 787/794（1990）

5) 則次：空気圧システムの設計と制御, パワーデザイン, 30 $-11,14 / 19$ (1990)

6）大西：電動機およびロボットの制御，電気学会誌，110-8, $657 / 660(1990)$

7）則次, 和田：マイコン制御による PCM 方式ディジタル空 気圧サーボの構成, 計測自動制御学会論文集, 23-3，253/ 259 (1987)

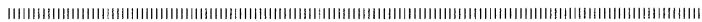

\section{[著 者 紹 介]}

則 次 俊 郎 (正会員)

(Vol. 31, No.1 参照)

高 岩 昌 弘（正会員）

(Vol. 31, No. 1 参照)

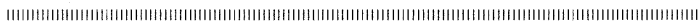

